M. B. SOBOLEVSKA, N. YU. NAUMENKO, D. V. HOROBETS

\title{
MATHEMATICAL SIMULATION OF DYNAMIC LOADS ON A HEAD CAR WITH A PASSIVE SAFETY SYSTEM IN A COLLISION OF IDENTICAL MO- TOR-CAR TRAINS
}

\author{
Institute of Technical Mechanics \\ of the National Academy of Sciences of U kraine and the State Space Agency of $U$ kraine, \\ 15 Leshko-Popel St., D nipro 49005, U kraine; ; e-mail: sobmb@ i.ua
}

\begin{abstract}
The topicality of this paper stems from the need to develop a modern home high-speed motor-car train with a passive safety system (PSS) in accordance with Ukrainian State Standard DSTU EN 15227 now in force in Ukraine, which regulates the passive safety of a passenger train in collisions with obstacles. A PPS includes energy-absorbing devices (EADs) designed for reducing the longitudinal forces in the intercar connections and the car accelerations in an emergency. The aim of the paper is a mathematical simulation of dynamic loads on the head car of a motor-car train with PSS elements in a collision of identical reference trains at a speed of $36 \mathrm{~km} / \mathrm{h}$ according to Scenario 1 of DSTU EN 15227. The scientific novelty of the paper is a mathematical model and program modules developed for the study a front collision of reference motor-car trains considered as chains of solid bodies connected with one another via essentially nonlinear elements. The force characteristic of an intercar connection accounts for the operation of the absorbing apparatus of the coupling devices, the possibility of the draw-and-buffer gears shifting into the undercar space, EAD plastic deformation, and the possibility of plastic deformations in the car structures. The proposed mathematical model gives the mean values of the car accelerations and plastic deformations for comparison with the permissible values according to DSTU EN 15227. Dynamic loads on the cars of a PPS-equipped motor-car train in a collision of identical reference trains were analyzed. Different variants of use of the energy-absorbing devices developed at the Institute of Technical Mechanics of the National Academy of Sciences of Ukraine and the State Space Agency of Ukraine were considered. The devices include lower-level ones to be mounted at the coupler level (EAD 1 of energy capacity $0.95 \mathrm{MJ}$, EAD 2 of energy capacity $0.25 \mathrm{MJ}$, and EAD 3 of energy capacity $0.3 \mathrm{MJ}$ ) and an upper-level one to be mounted in the front underwindow part of a head car (EAD UL of energy capacity 0.12 MJ). Dynamic loads on the cars of PSS-equipped trains in their front collision were studied. It was found that the proposed passive protection (the front parts of each of the $80 \mathrm{t}$ head cars are equipped with two EAD and two EAD UL devices, their tail parts are equipped with two EAD 3 devices, and the $64 \mathrm{t}$ intermediate cars are equipped with two EAD 3 devices at the front and at the rear) meets the DSTU EN 15227 requirements for Scenario 1. The proposed mathematical model and the results obtained may be used in designing head and intermediate cars for a home motor-car passenger train in accordance with the DSTU EN 15227 requirements.
\end{abstract}

Keywords emergency collision, head car, passenger motor-car train, energy-absorbing devices, passive safety system.

1. Ukrainian State Standard DSTU EN 12663-1:2018 (EN 12663-1:2010 + A1:2014, IDT). Railway transport. Structural requirements for railway vehicle bodies. Part 1. Locomotives and passenger cars (and an alternative method for freight cars). 2018. 18 pp. (in Ukrainian).

2. Ukrainian State Standard DSTU EN 15227:2015 (EN 15227:2008+A1:2010, IDT). Railway transport. Crashworthiness requirements for railway vehicle bodies. 2016. 37 pp. (in Ukrainian).

3. European Standard EN 12663-1: 2010. Railway applications - Structural requirements of railway vehicle bodies. Brussels, 2010. $18 \mathrm{pp}$.

4. European Standard EN 15227: 2008. Railway applications - Crashworthiness requirements for railway vehicle bodies. Brussels, 2008. $37 \mathrm{pp}$.

5. Roberts J., Fraikin B., Leveque D. Development and validation of a regional train platform to the requirements of EN 15227. Proc. of the 7th Int. Symp. 20-21.11.2008 on Passive Safety of Rail Vehicles. Innovation in Passive Safety and Interior Design (Berlin: IFV Bahntechnik e.V.). 2008. V. 17. Pp. 237-248.

6. Series 422 electric train. Zhelesnye Dorigi Mira. 2010. No. 5. Pp. 37-49. (in Russian).

7. Railway vehicle production in the East-European countries. Zhelesnye Dorigi Mira. 2019. No. 3. Pp. 61-65. (in Russian). 
8. Nazarov O. N. Technical features of the Velaro Rus high-speed electric train. Tekhnika Zheleznykh Dorog. 2009. No. 1. Pp. 18-33. (in Russian).

9. Mangler R. "Desiro rus": a promising electric train for commuter traffic in Russia. Lokomotiv-Inform. 2012. No. 10. Pp. 20-24. (in Russian).

10. Bogatyrev B., Moguchev A. EP2D electric train: the future is already here. Transmashholding: Zhurnal dlya Partnerov. 2016. No. 2 (6/2016). Pp. 4-11. (in Russian).

11. Interstate Standard GOST 32410-2013. Emergency crash-systems for railway passenger vehicles. Technical requirements and inspection methods. Moscow: Standartinform, 2014. 11 pp. (in Rus-sian).

12. Ignatov G. S. Interregional two-system electric train. Lokomotiv-Inform. 2012. No. 12. Pp. 16-19. (in Russian).

13. Branch Standard OST 32.193-2002. Clearance-free coupling devices for locomotive-hauled passen-ger trains and motor-car trains of $1520 \mathrm{~mm}$ gauge railways. Engagement contour and mounting di-mensions. Introduced on Sept. 1, 2002. Railway Ministry of Russia. 2002. 14 pp. (in Russian).

14. Sobolevskaya M. B., Sirota S. A. Basic concepts of passive safety of high-speed passenger trains at crash collisions. Teh. Meh. 2015. No.1. Pp. 84-96. (in Russian).

15. Naumenko N. Yu., Sobolevska M. B., Khizha I. Yu. Estimation of dynamic loads on a reference train with a passive safety system in its collisions with an identical train and a freight car. Teh. Meh. 2017. No. 3. Pp. 72-83. (in Russian).

https://doi.org/10.15407/itm2017.03.072 